\title{
Using Quizizz in Learning Assesment with Science Literacy Oriented in Science Learning
}

\author{
Mela Agustia $^{1 *}$, Charolin Aprilia1 ${ }^{1}$,Jenni Sari ${ }^{1}$, Darul Hikmah ${ }^{1}$, Risnita ${ }^{2}$ \\ ${ }^{1}$ Departement of Science Education, Graduate Program, Jambi University, Jambi, Indonesia \\ ${ }^{2}$ Faculty of Teacher Training and Education, Islamic State University STS, Jambi, Indonesia \\ *Corresponding authorE-mail: melaagustia5@gmail.com
}

\begin{abstract}
Manuscript received 1 Jan 2021; revised 10 Jan 2021; accepted 15 Jan 2021. Date of publication 20 Jan 2021

In the covid-19 era, activities are forced to be done from home, including learning activities. Because of the limited network, students' interest in doing assignments becomes low. Thus teachers tend to ignore the assessment of learning outcomes during the pandemic. Even though assess learning outcomes is very important to do, one of them is a daily test which aims to find out the extent to which students understand the lesson. This study aims to determine the use of the Quizizz applicationwith science literacy oriented as a media for assessing learning outcomes during the study. The research method used is applied research, namely by implementing the Quizizz application in science literacy for online assessment. The data collection method used was a questionnaire. Quantitative data collection was obtained with closed questions. Questionnare is given after students doing daily tests using Quizizz with science literacy oriented. The daily test consists of 20 multiple choice questions of Motion with 10 literacy discourses. The result of daily test is devided into three part, namely high, medium and low. Based on the result of daily test 13 students who get high accuracy score, 9 students in medium cluster and 8 students in low cluster. Overall students give positive responses to using Quizizz with science literacy oriented and agree to be used in the daily test. Based on students perceptions, the use of Quizizz is very interest and science literacy help them remember what they have learned.. However, there needs to be assistance from the teacher when new students use Quizizz for the first time.
\end{abstract}

Keywords: Daily Test, Quizizz, Science Literacy, Science Learning

\section{Introduction}

In order to prevent the spread of the covid-19 virus, we are forced to limit our activities and stay away from crowds. This also has an impact on education which causes learning must be done online from home. As a result, various learning adjustments are made.

One of the most important parts of learning is the assessment and evaluation of learning outcomes. Evaluation is defined as selective exercise that attempts to systematically and objectively assess progress towards and the achievement of an outcome [1]. However, teachers have difficulty in assessing students' learning outcomes. To overcome this problem the teachers prefer an alternative assessment in the form of a portfolio assessment, but in the reality it was found that only a few students collect the assignments given by the teachers. Online learning makes students' interest in submitting assignments decline, because they are not directly supervised by the teachers. Meanwhile, for daily tests, teachers are more likely to eliminate them during the pandemic, this is by the reason of daily tests which have potential for students to cheat and are less effective since the teachers do not supervise students directly. In fact, daily tests are very important to do in order to find out the extent to which students understand the material that has been taught by the teacher [2].

To achieve educational goals, teachers must ensure that teaching and learning activities should be continued even though from home. Learning innovation is a solution that needs to be designed and implemented by teachers by maximizing existing media such as online media [3].

One of the innovations that can be done is by utilizing technological sophistication in accordance with the students, including the Quizizz application. Game Quizizz is a game-based educational app, which brings multi-game activities to the classroom and makes in-class practice interactive and fun. By implementing Quizizz Game, students can do exercises in class on their electronic devices. Quizizz games have game characteristics such as avatars, themes, memes, and music that have interesting effects during the learning process. Quizizz allows students to compete with each other and motivates them to learn so that learning outcomes can be improved. Students take quizzes at the same time in class and see their live ranking on the leaderboard [4] [5]. 
By using Quizizz, it is hoped that it can help teachers increase students' enthusiasm in taking daily tests. In line with research conducted by Zhao [6] The Students like the features of this app, especially the leaderboard, which shows the live ranking of their performance and motivates them to study. They agree that Quizizz helps them concentrate in class and reduces their test anxiety. They prefer doing in-class exercises using Quizizz than on paper [7].

\section{Literature Review}

Several previous studies have used the Quizizz application, such as Purba [8] which utilizes the Quizizz application as an effort to increase student learning concentration in physics chemistry courses and concluded that learning evaluation using quizizz helps improve student learning concentration. Mulyati \& Evendi [9] in their research proved that Quizizz application can improve student learning outcomes. Khasanah \& Lestari [10] in their research, This study's results have implications for choosing Quizizz media and the relationship between learning media interactions with students' learning independence.

Another research, Darmawan, Daeni, \& Listiaji [11] uses Quizizz as an online assessment for science learning and concluded that online assessment using Quizizz is very beneficial for teachers or lecturers because they can provide test results reports quickly along with their analysis and increased student motivation and interest. Anak Yunus \& Hua [12] in their research concluded that implementation of online interactive games such as Quizizz can be seen as an exhilarating, creative, and impactful means of shifting from the conventional way of imparting knowledge, especially to millennials. This educational game provides so many benefits that can certainly be felt in learning media, because this media is interesting and can motivate brain work and time management [13].

One of the demands of education today is to improve students' critical thinking skills. The critical thinking skill is very important for students to help them in solving problems. The critical thinking skill can be built through finding based learning using science literacy approaches, Science literacy is one of the parameters in determining the human development index which is strongly influenced by the quality of education [14]. Scientific literacy is an element of life skills that must be the key outcome of the education process for children aged 15 years. For that reason, children aged 15 years (towards the end of compulsory education) are deemed necessary to have an adequate level of scientific literacy, both for those who will continue their studies in the field of science or those who do not [15]. Science literacy should be applied because including one of the important abilities that must be owned by students and can be used to solve problems in life everyday that demands that one must scientific thinking [16].

Several previous studies have used the science literacy, such as Helendra \& Sari [15] in their research proved that a scientific literacybased assessment instrument on the excretory system and respiratory system material is feasible to use. Sutiani, Situmorang, \& Silalahi [14] concluded that learning resource on inquiry learning model with science literacy has a significant contribution to improve students' critical thinking skills in chemistry and ultimately improve students' achievements. The effectiveness aspect in improving science literacy ability indicated by the $\mathrm{N}$-gain score average of 0.88 , which is in the high category [17] [18].

\section{Method}

The research method used is applied research, namely by implementing the Quizizz application in science literacy for online assessment. The subjects of this study were 30 students, SMPN 11 Jambi City in the Science learning. The instruments used were the online test questions for daily tests with learning multimedia Quizizz and questionnaire to see students' responses. Figure 1 shows the research steps.

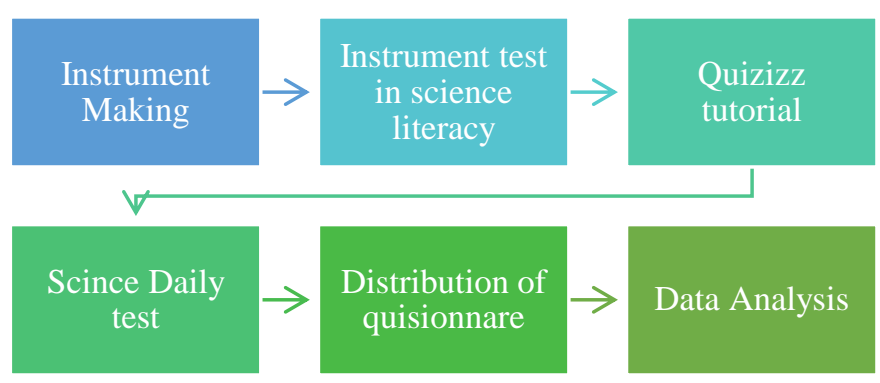

Fig 1. Research step

The daily test consists of 20 multiple choice questions of Motion with 10 literacy discourses on the Quizizz application.The questions displayed on the Quizizz application is shown in Figure 2.

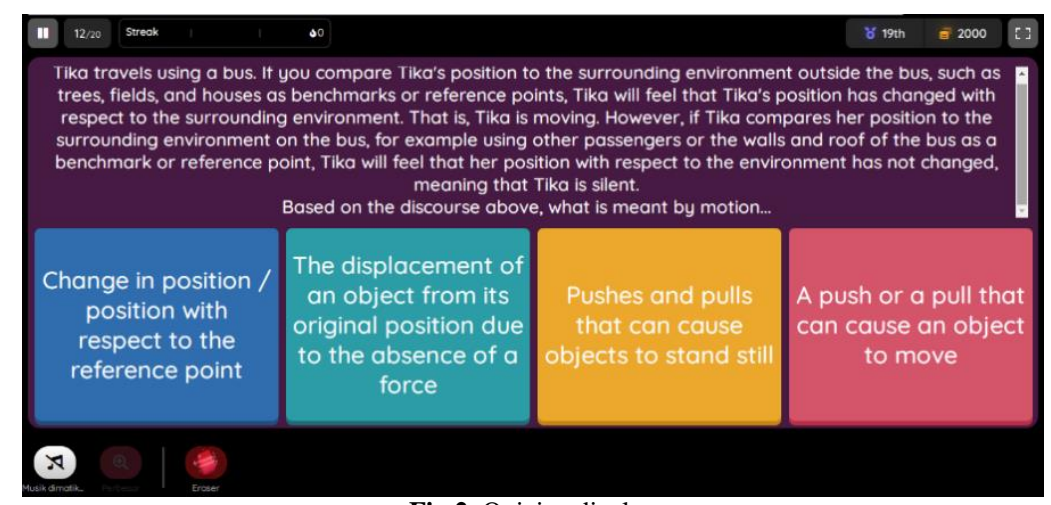

Fig 2. Quizizz display 
The data collection method used is questionnaire. Questionnaire is given to students after doing daily test by using Quizizz application with science literacy oriented to figure out students' perception about daily test with science literacy. The questionnaireconsists of 10 closedstatements with multiple choice strongly agree, agree, disagree, strongly disagree. The Questionnaire given using google forms.

Table 1. Survey Questions

\begin{tabular}{|c|c|}
\hline No. & Survey Questions \\
\hline 1 & Quizizz is easy to use for daily test \\
\hline 2 & Quizizz questions with scientific literacy help me remember what I have learned \\
\hline 3 & $\begin{array}{l}\text { Quizizz questions with scientific literacy improve my understanding of the material } \\
\text { I'm studying }\end{array}$ \\
\hline 4 & Science daily test using Quizizz is fun \\
\hline 5 & $\begin{array}{l}\text { Quizizz questions with Scientific Literacy increase my interest in doing science as- } \\
\text { signments }\end{array}$ \\
\hline 6 & I am motivated to get the highest rank and score when using Quizizz \\
\hline 7 & $\begin{array}{l}\text { I feel more concentrated when answer the questions on Quizizz with science literacy } \\
\text { oriented }\end{array}$ \\
\hline 8 & using the Quizizz application can reduce cheating during science tests \\
\hline 9 & I think the online test with the help of quizizz is going well \\
\hline 10 & $\begin{array}{l}\text { In my opinion, the daily science test with the help of science literacy-oriented quiz- } \\
\text { izz takes place effectively and efficiently }\end{array}$ \\
\hline
\end{tabular}

\section{Result and Discussion}

Using the Quizizz application can also make learning and online learning fun. Teachers who give questions and take advantage of the features in the Quizizz application are able to attract students' attention so that students are happy in participating in the online learning process.One of the advantages of Quizizz is that the score can be seen directly and immediately after the test is carried out. We can see that the Quizizz application can provide detailed student daily test report both in terms of accuracy, final score and student's ranking after completing one question. According Haddar and Juliano [19] The advantages of using the Quizizz application can be seen directly and use of the Quizizz application can also evaluate students independently.

\subsection{Result student tests using Quizizz with science literacy oriented}

The Quizizz application can display score cluster data into 3 parts, namely high, medium, and low. Students can achieve high score when they get score above the average score of class. Student achieve medium score when they get exactly the average score of class. Students can achieve low score when they get score under the average score of class [7] [20]. From the results of student tests using Quizizz, the following results were obtained :

Table 2. Result of Daily Test with Quizizz

\begin{tabular}{|c|c|c|c|}
\hline Player & Score & Accuracy & Cluster \\
\hline Player 1 & 15280 & $80 \%$ & High \\
\hline Player 2 & 12920 & $75 \%$ & High \\
\hline Player 3 & 12920 & $75 \%$ & High \\
\hline Player 4 & 12610 & $70 \%$ & High \\
\hline Player 5 & 11840 & $70 \%$ & High \\
\hline Player 6 & 11150 & $65 \%$ & High \\
\hline Player 7 & 10890 & $65 \%$ & High \\
\hline Player 8 & 10440 & $60 \%$ & High \\
\hline Player 9 & 10420 & $60 \%$ & High \\
\hline Player 10 & 10280 & $60 \%$ & High \\
\hline Player 11 & 9930 & $60 \%$ & High \\
\hline Player 12 & 9900 & $60 \%$ & High \\
\hline Player 13 & 9420 & $60 \%$ & High \\
\hline Player 14 & 8680 & $50 \%$ & Medium \\
\hline Player 15 & 8590 & $55 \%$ & Medium \\
\hline Player 16 & 8530 & $55 \%$ & Medium \\
\hline Player 17 & 8370 & $50 \%$ & Medium \\
\hline Player 18 & 8360 & $50 \%$ & Medium \\
\hline Player 19 & 8320 & $50 \%$ & Medium \\
\hline Player 20 & 8140 & $50 \%$ & Medium \\
\hline Player 21 & 8080 & $50 \%$ & Medium \\
\hline Player 22 & 7950 & $50 \%$ & Medium \\
\hline Player 23 & 7940 & $45 \%$ & Low \\
\hline Player 24 & 6190 & $40 \%$ & Low \\
\hline Player 25 & 3420 & $35 \%$ & Low \\
\hline Player 26 & 3400 & $35 \%$ & Low \\
\hline Player 27 & 3220 & $20 \%$ & Low \\
\hline Player 28 & 3150 & $25 \%$ & Low \\
\hline Player 29 & 2950 & $20 \%$ & Low \\
\hline Player 30 & 1950 & $20 \%$ & Low \\
\hline
\end{tabular}

Based on table 1, we can see that students who get the highest accuracy score is $80 \%$. The average of students result of $52 \%$ with standard deviation of $16.15 \% .13$ students whoget high accuracy scores in clusters have an average of $66.15 \%$ with a standard deviation of $6.83 \%$. From the result three of students have achieved good scores according to school standard (more than 74\%). In medium clusters there are 9 students with average of $51.11 \%$ and a standard deviation of $2.07 \%$. While in low clusters there are 8 students with with average of $30 \%$ and a standard deviation of $9.3 \%$. 
As many as 13 students are in the high cluster, this shows that using Quizizz can improve students motivation. One of the reasons is because the questions are designed to be science-oriented, which can help students recall the lessons they have learned and students become more challenged when they see the leaderboard.

\subsection{Student perception}

There are several questions posed to students to get responses regarding the use of this Quizizz application.

1. Quizizz is easy to use for daily test

This Question aims to find out students' opinions about the ease of using Quizizz. Data on the ease of use of Quizizz are as follows:

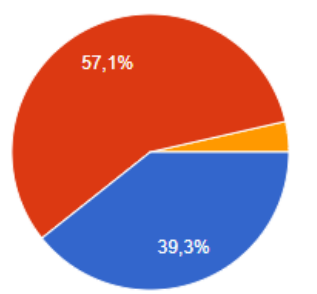

Strongly agree

agree

Disagree

- Strongly disagree

Fig 3. Ease of use percentage

Based on figure 3. Questions related to the ease of using Quizizz with 39.3\% of students answered strongly agree and $57.1 \%$. With $96.4 \%$ of students agree, this shows that the student's response to the daily test using Quizizz is very good. According to students Quizizz is very easy to use for daily tests.

2. Quizizz questions with science literacy help me remember what I have learned

This question aims to determine students' perceptions of the question with science literacy oriented

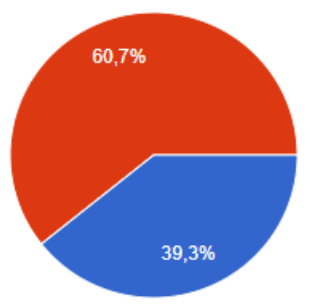

Strongly agree
Agree

Disagree

Strongly disagree

Fig. 4: science literacy

Based on figure 4 , we can see that $60.7 \%$ of students agree that science literacy can help they remember what they have learned and $39.3 \%$ of students think that they strongly agree. This proves that students are helped by the existence of science literacy.

While for the other 8 Question about students perception show by the following table 3.

Table 3. Result of survey questions

\begin{tabular}{|c|c|c|c|c|}
\hline Survey Questions & $\begin{array}{l}\text { Strongly } \\
\text { agree }\end{array}$ & Agree & Disagree & $\begin{array}{l}\text { Strongly } \\
\text { disagree }\end{array}$ \\
\hline $\begin{array}{l}\text { Quizizz questions with scientific literacy improve my } \\
\text { understanding of the material I'm studying }\end{array}$ & $63.3 \%$ & $33.3 \%$ & $3.3 \%$ & - \\
\hline Science daily test using Quizizz is fun & $43.3 \%$ & $50 \%$ & $6.7 \%$ & - \\
\hline $\begin{array}{l}\text { Quizizz questions with Scientific Literacy increase my } \\
\text { interest in doing science assignments }\end{array}$ & $33.3 \%$ & $56.7 \%$ & $10 \%$ & - \\
\hline $\begin{array}{l}\text { I am motivated to get the highest rank and score when } \\
\text { using Quizizz }\end{array}$ & $46.7 \%$ & $50 \%$ & $3.3 \%$ & - \\
\hline $\begin{array}{l}\text { I feel more concentrated when answer the questions on } \\
\text { Quizizz with science literacy oriented }\end{array}$ & $33.3 \%$ & $56.7 \%$ & $10 \%$ & - \\
\hline $\begin{array}{l}\text { using the Quizizz application can reduce cheating dur- } \\
\text { ing science tests }\end{array}$ & $30 \%$ & $53.3 \%$ & $16.7 \%$ & - \\
\hline $\begin{array}{l}\text { I think the online test with the help of quizizz is going } \\
\text { well }\end{array}$ & $40 \%$ & $53.3 \%$ & $6.7 \%$ & - \\
\hline $\begin{array}{l}\text { In my opinion, the daily science test with the help of } \\
\text { science literacy-oriented quizizz takes place effectively } \\
\text { and efficiently }\end{array}$ & $63.3 \%$ & $30 \%$ & $3.35 \%$ & $3.35 \%$ \\
\hline
\end{tabular}

Based on tables 3 above most of the students answered with positive answers about using Quizizz with science literacy in science learning, such as Quizizz questions with scientific literacy improve my understanding of the material I'm studying, $63.3 \%$ students answer agree and $33.3 \%$ student answers strongly agree. On question Science daily test using Quizizz is fun, 50\% students answer strongly agree and $43.3 \%$ students answer agree. According Swarniti [21] Quizizz application is a learning application that is fun, effective, not boring, varied, challenging, simple, and can be used anywhere. This proves that the use of Quizizz is fun in learning. On question Quizizz questions with Scientific Literacy increase my interest in doing science assignments, 56.7\% student answer agree and 33.3\% students answer strongly agree, while the other $10 \%$ student answer disagree. 


\section{Conclusion}

Based on the results of this study, it can be concluded that in general Quizizz is very useful for daily tests. Daily test using Quizizz with science literacy can motivate students and make it easier for students to recall the lessons they have learned. Using Quizizz can reduce cheating and make online daily tests more effective. The existence of a leaderboard also attracts students' attention and they feel challenged to be at the top of the leaderboard.

\section{References}

[1] D. M. Mertens, "Research and Evaluation in Education and Psychology," Res. Eval. Educ. Psychol., 2010.

[2] B. Dwi Cahyono and D. Sulastri, "Development Of Electrical Installation Learning Me-dia With Delphi Language," Int. J. Eng. Sci. Inf. Technol., vol. 1, no. 3, 2021, doi: 10.52088/ijesty.v1i3.81.

[3] D. Riyan Rizaldi, A. Doyan, Z. Fatimah, M. Zaenudin, and M. Zaini, "Strategies to Improve Teacher Ability in Using The Madrasah E-Learning Application During the COVID-19 Pandemic," Int. J. Eng. Sci. Inf. Technol., vol. 1, no. 2, 2021, doi: 10.52088/ijesty.v1i2.47.

[4] B. Mulatsih, "Penerapan Aplikasi Google Classroom , Google Form , Dan Quizizz Dalam Pembelajaran Kimia Di Masa Pandemi," ideguru J. Karya Ilm. Guru, vol. 5, no. 1, 2020.

[5] S. Dwi Putra and V. Yasin, "MDA Framework Approach for Gamification-Based Elementary Mathematics Learning Design," Int. J. Eng. Sci. Inf. Technol., vol. 1, no. 3, 2021, doi: 10.52088/ijesty.v1i3.83.

[6] F. Zhao, "Using quizizz to integrate fun multiplayer activity in the accounting classroom," Int. J. High. Educ., vol. 8, no. 1, 2019, doi: 10.5430/ijhe.v8n1p37.

[7] D. Ismail, "Recognition System Of The Al Qur'an Surah Al-Falaq Verse 1-5 Through Voice Using Ada-Boost," Int. J. Eng. Sci. Inf. Technol., vol. 1, no. 3, 2021, doi: 10.52088/ijesty.v1i3.85.

[8] L. S. L. Purba, "The effectiveness of the quizizz interactive quiz media as an online learning evaluation of physics chemistry 1 to improve student learning outcomes," in Journal of Physics: Conference Series, 2020, vol. 1567, no. 2, doi: 10.1088/1742$6596 / 1567 / 2 / 022039$.

[9] S. Mulyati and H. Evendi, "Pembelajaran Matematika melalui Media Game Quizizz untuk Meningkatkan Hasil Belajar Matematika SMP,” GAUSS J. Pendidik. Mat., vol. 3, no. 1, 2020, doi: 10.30656/gauss.v3i1.2127.

[10] K. Khasanah and A. Lestari, "The Effect of Quizizz and Learning Independence on Mathematics Learning Outcomes," Tadris J. Kegur. dan Ilmu Tarb., vol. 6, no. 1, 2021, doi: 10.24042/tadris.v6i1.7288.

[11] M. S. Darmawan, F. Daeni, and P. Listiaji, "The Use of Quizizz as an Online Assessment Application for Science Learning in The Pandemic Era," Unnes Sci. Educ. J., vol. 9, no. 3, 2020.

[12] C. C. A. Yunus and T. K. Hua, "Exploring a gamified learning tool in the ESL classroom: The case of Quizizz," Journal of Education and e-Learning Research, vol. 8, no. 1. 2021, doi: 10.20448/JOURNAL.509.2021.81.103.108.

[13] U. H. Salsabila, I. S. Habiba, I. L. Amanah, N. A. Istiqomah, and S. Difany, "Pemanfaatan Aplikasi Quizizz Sebagai Media Pembelajaran Ditengah Pandemi Pada Siswa SMA,” J. Ilm. Ilmu Terap. Univ. Jambi|JIITUJ|, vol. 4, no. 2, 2020, doi: 10.22437/jiituj.v4i2.11605.

[14] A. Sutiani, M. Situmorang, and A. Silalahi, "Implementation of an Inquiry Learning Model with Science Literacy to Improve Student Critical Thinking Skills,” Int. J. Instr., vol. 14, no. 2, 2021, doi: 10.29333/iji.2021.1428a.

[15] H. Helendra and D. R. Sari, "Pengembangan Instrumen Asesmen Berbasis Literasi Sains tentang Materi Sistem Ekskresi dan Sistem Pernapasan," J. Ilm. Pendidik. Profesi ..., 2021.

[16] R. Setiyoningtyas and Kasmui, "PENGEMBANGAN QUIZIZZ-ASSISTED TEST BERBASIS LITERASI PESERTA DIDIK PADA MATERI LARUTAN ELEKTROLIT NONELEKTROLIT," Chem. Educ., vol. 9, no. 2, 2020.

[17] G. Rajadewi and M. Putri, "Student Worksheets with Scientific Literacy Oriented on Hydrolysis Matter by Utilizing Surrounding Materials as an Alternative Practicum in Pandemic Era," J. Educ. Sci., vol. 5, no. 3, 2021.

[18] S. Kumari and A. Harikrishnan, "Importance of Financial literacy For Sustainable Future Environment: A Research Among People In Rural Areas With Special Reference To Mandi District,Himachal Pradesh,” Int. J. Eng. Sci. Inf. Technol., vol. 1, no. 1, 2021, doi: 10.52088/ijesty.v1i1.36.

[19] G. Al Haddar and M. A. Juliano, "Analisis Media Pembelajaran Quizizz dalam Pembelajaran Daring pada Siswa Tingkat Sekolah Dasar,” EDUKATIF J. ILMU Pendidik., vol. 3, no. 6, pp. 4794-4801, 2021.

[20] O. Oktamianiza, D. Maisa Putra, Y. Yulia, A. Fahira, and A. Afridon, "Analysis of Differences in Tariff for Health Service Based on Sustability of Diagnosis on Admision and Summary Discharge Form with INA-CBGs Verification," Int. J. Eng. Sci. Inf. Technol., vol. 1, no. 3, 2021, doi: 10.52088/ijesty.v1i3.114.

[21] N. W. Swarniti, "Efektivitas Penggunaan Aplikasi Quizizz Dalam Proses Pembelajaran Bahasa Inggris Bagi Mahasiswa," in Seminar Nasional Teknologi Pembelajaran, 2021. 